\title{
Related trade variety, foreign-domestic spillovers and regional employment in Hungary
}

\author{
ZOLTÁN ELEKES ${ }^{1,2,3 *}$ (1) and BALÁZS LENGYEL ${ }^{1,4,5}$ (])
}

\footnotetext{
${ }^{1}$ Agglomeration and Social Networks Lendület Research Group, Centre for Economic and Regional Studies, Tóth Kálmán u. 4, Budapest, H-1097, Hungary

${ }^{2}$ Department of Geography, Umeå University, Umeå, Sweden

${ }^{3}$ Institute of Economics and Economic Development, Faculty of Economics and Business Administration, University of Szeged, Szeged, Hungary

${ }^{4}$ Laboratory for Networks, Technology \& Innovation, Institute of Advanced Studies, Corvinus University of Budapest, Budapest, Hungary

${ }^{5}$ International Business School Budapest, Budapest, Hungary
}

Received: October 31, 2018 • Revised manuscript received: May 2, 2019 • Accepted: July 26, 2019

(c) 2020 The Author(s)

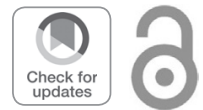

\begin{abstract}
This paper investigates the role of extra-regional capabilities in regional economic development in a Central and Eastern European context. This is done by analysing the association between the related variety of manufacturing import and export of domestic- and foreign-owned firms on the one hand, and regional employment in manufacturing export on the other. By means of a panel regression framework applied to the Hungarian microregions between 2000 and 2011, we find that domestic firms, in particular, benefit from the related variety of export activities in the regions, while import related to existing export activities is beneficial amongst both foreign and domestic firms. Furthermore, bridging the technological gap between foreign companies and the host economy requires stronger technological relatedness, unless domestic firms have experience in importing.
\end{abstract}

\section{KEYWORDS}

related variety, international trade, MNEs, host economy, regional growth

JEL CLASSIFICATION INDICES

B52, 030, R11, R12

*Corresponding author. E-mail: elekes.zoltan@krtk.mta.hu 


\section{INTRODUCTION}

International trade has long been considered a decisive underlying mechanism in regional development because export is a major source of income for regions, which can be multiplied by internal input-output relations (North 1955), and also because the level of success in international trade is linked to the cumulative emergence of agglomeration economies in the region (Krugman 1991). The intensification of globalisation gave rise to empirical explorations on this matter (for an overview, see Brülhart 1998), and also brought the role of foreign firms in regional development into the focus of interest (Dicken 1994; Young et al. 1994; Beugelsdijk et al. 2010; Iammarino - McCann 2013). This is because multinational enterprises (MNEs) are more active than other firms in the global division of labour (Greeneway - Keller 2007), because spillovers from foreign-owned firms ${ }^{1}$ increase the productivity of domestic-owned companies (Haskel et al. 2007), and also decrease the entry cost for other potential exporters (Aitken et al. 1997). However, the impact of foreign firms in less developed regions is far from being clear since the local economies might differ in the ways in which they can exploit the presence of foreign firms through production links and spillovers (Soci 2003; Görg - Greeneway 2004; Phelps 2008; Pavlínek - Žížalová 2016; Csiki et al. 2019).

The literature of evolutionary economic geography (EEG) stresses the role played by technological relatedness in local knowledge spillovers (Frenken et al. 2007), on the grounds that the co-located firms might learn from each other if their technological profiles are not too different, but not too similar either (Boschma 2005). It has been shown that the variety of technologically related industries in the regions - i.e. related variety - fosters regional economic growth (for an overview, see Content - Frenken 2016), and the relatedness of the new activities to the existing ones conditions the economic diversification of countries and regions (for an overview, see Hidalgo et al. 2018). As an extension, Boschma - Iammarino (2009) proposed that import could be considered as inflow of external knowledge into the region, and could therefore create new growth potentials if it was related but not identical to the pre-existing productive knowledge of the region, captured by its export portfolio. Additionally, one can argue that if the regions are the units of production, imports are the inputs and exports are the outputs, then combining related rather than similar products yields more complex products, representing more valueadded, leading to higher economic growth.

However, our understanding on how relatedness facilitates regional development in FDIdriven economies is still limited. We aim to show that foreign firms affect regional employment through trade-mediated knowledge spillovers to domestic firms. In order to do so, we rely on a panel dataset of Hungarian manufacturing firms that participate in international trade. The dataset contains balance sheet variables, firm location and the value of export and import products by SITC product codes for the period between 2000 and 2011 . We measure the relatedness of international trade activities of foreign and domestic firms at the regional level, adapting the measurement approach of Boschma - Iammarino (2009). We argue that the Hungarian case is suitable to discuss the above issue because the country has a small and open economy, which means that most of the inputs has to be imported (Halpern et al. 2015), and

\footnotetext{
${ }^{1}$ For the sake of simplicity, we use 'foreign firms' in short for 'foreign-owned firms' and 'domestic firms' in short for 'domestic-owned firms'.
} 
also because international trade in manufacturing is dominated by a small set of foreign firms (Antalóczy 2012).

Our main findings regarding the relatedness within the foreign and domestic subsets of manufacturing companies indicate that domestic firms in particular benefit from the related variety of export activities in the regions, while import related to existing export is beneficial amongst both foreign and domestic firms. With respect to the relatedness between the international trade activities of foreign and domestic firms we find that bridging the technological gap between foreign companies and the host economy requires stronger technological proximity, however, weaker technological proximity may be bridged if domestic firms have experience in importing.

With these results we wish to contribute to the literature of EEG in two ways. First, by further exploring the mediating role of relatedness in accessing extra-regional productive capabilities, and how 'borrowing' such capabilities may be a vehicle for learning for the host region. Second, by doing so we also draw more attention to the regions in Central and Eastern European (CEE) countries, that are much more dependent on the international value chains of MNEs, and the knowledge spillovers from these to the host economy, compared with the regions of more developed economies.

In the following section we review the literature on related variety and the significance of foreign firms in CEE, and describe the economic context of the Hungarian import and export activities, including the historically formed duality of foreign and domestic companies. Next, we elaborate on our research design by describing the quantitative approach and explaining our key variables. We report our findings in the results section, then close the paper with our conclusions.

\section{THEORETICAL BACKGROUND}

It has been thoroughly demonstrated that firms benefit from co-location through various forms of positive externalities, and the role of these externalities in understanding regional growth is central to the literature on economic geography to this day (Glaeser et al. 1992; Henderson et al. 1995; Beaudry - Schiffauerova 2009; Caragliu et al. 2016). Among these externalities, knowledge spillovers within and between industries are usually in the centre of attention. Frenken et al. (2007), however, proposed that it is not the spillovers within industries (specialisation), nor the spillovers between industries (variety of economic activities) per se what matters for growth, but the extent of related variety in a region. Related variety is composed of industries that are not too close in their technological knowledge base, so that they can learn from each other, but not too far either, so that they are able to understand each other (Boschma 2005). The variety of industries too dissimilar in their knowledge base to enable effective learning is then considered unrelated variety. Empirical evidence so far systematically showed that related variety is beneficial for regional employment growth in particular (for an overview, see Content - Frenken 2016).

New knowledge may reach regions from the outside as well and regional growth may depend on combining external knowledge with local capabilities. Firms with access to export markets are more inclined to innovate (Damijan - Kostevc 2010), while import and foreign investments can be linked to access and absorption of new knowledge (Marwah - Tavakoli 2004). Additionally, an increase in import puts competitive pressure on domestic companies leading either 
to increased innovation potential (Awokuse 2008), or diminished chance of survival. Boschma Iammarino (2009) showed that the variety of import is beneficial for regional growth particularly when it is related to existing export activities, i.e. some elements of productive knowledge for a new product were already in place. In addition to that, export and import tend to be present at the same time even in industries with revealed comparative advantage in export, and successful presence in export is coupled with a substantial import component (Békés et al. 2013).

MNEs can be considered as another channel for extra-regional capabilities. Evidence indicates that technological relatedness to the co-located foreign firms fosters local product discoveries (Lo Turco - Maggioni 2019), and that relatedness is an important driver of crosssectoral employment-enhancing spillovers from MNEs (Cortinovis et al. 2020). Similar to other CEE countries, the investments of MNEs were a driving force behind regional economic development after the post-socialist transition in Hungary (Radosevic 2002; Resmini 2007; Lengyel - Leydesdorff 2011, 2015; Lengyel - Szakálné Kanó 2014). Productivity spillovers have been found between foreign and domestic companies (Csáfordi et al. 2020), that decrease as geographical distance grows (Halpern - Muraközy 2007). However, the interactions between the co-located foreign and domestic companies evolved slowly, and technological relatedness between them affected regional employment growth and entry-exit of domestic companies only in the 2000s (Lengyel - Szakálné Kanó 2013; Szakálné Kanó et al. 2019).

These phenomena may be due to the fact that only those domestic companies could benefit from the presence of foreign firms that were productive enough to absorb the positive externalities (Békés et al. 2009); and the productivity of domestic companies evolved gradually. It is often proposed that foreign firms may generate knowledge spillovers to domestic companies in the form of increased human capital, management routines and new technologies. However, in general, domestic firms in Hungary are less innovative (Halpern - Muraközy 2010), and foreign firms are usually less embedded in the local production networks compared with domestic firms (Barta 2005). Spillovers between foreign and domestic companies occur both horizontally, realised without direct backward or forward linkages, and vertically as domestic firms are trained or learn to imitate foreign firms through value-chain linkages (Pavlínek - Žížalová 2016).

For these reasons, the benefits of relatedness may be unequally available for domestic and foreign firms, leading us to propose that spillovers between import and export activities may be structured along firm ownership.

\section{EMPIRICAL RESEARCH DESIGN}

\subsection{Data and sampling}

To test the above-said, we use firm-product level data that matches balance-sheet and trade information collected by the Hungarian Central Statistical Office (HCSO). The balance-sheet data was compiled from financial statements associated with tax declaration submitted to the National Tax Authority in Hungary by legal entities using double-entry bookkeeping. The foreign trade data was collected by the HCSO. The data on foreign trade outside the EU is based 
on customs documents, while data on trade inside the EU is based on surveys collected from firms. The dataset consists of the value of all international export and import flows in Hungarian Forint $^{2}$ (HUF) by each firm, detailed by SITC product classes at the 4-digit level. Price indexes of SITC product classes provided by the HCSO were used to deflate current values of trade flows (Year $2000=100 \%$ ). Firm level information includes the location of company seat (microregion level), the 4-digit level NACE code of the firms' main activity, the number of employees and various balance sheet data. The dataset consists of data ranging from 2000 to 2011.

The sample was narrowed down to manufacturing firms because company seat data are more likely to represent the location of actual production activities in the case of manufacturing industries (Békés - Harasztosi 2013), and because this way we exclude those firms that only trade and have no productive activities, and consequently are unlikely to benefit from spillovers of productive knowledge. The firm sample was further narrowed to those that had at least two employees throughout the 2000-2011 period. The two-employee limit is adequate to exclude unreliable observations, but it is also loose enough to retain a large number of domestic firms. This is important as domestic firms tend to be much smaller than foreign ones, and a higher threshold would introduce bias towards foreign companies.

For analytical purposes we considered a firm as 'foreign-owned', if more than $50 \%$ of the total equity capital of the firm was in foreign ownership. We opted for this threshold because controlling interest in a firm may be a prerequisite for changes to be induced by a foreign owner. Additionally, the vast majority of foreign entities in Hungary either obtained more than $90 \%$ of total equity capital of a firm or none at all.

Hungarian urban microregions (LAU1) were chosen as the spatial unit of analysis, as the benefits of co-location tend to be spatially bounded. As of 2013, there were 175 microregions (kistérség) in Hungary ${ }^{3}$, which were created in harmony with EU zoning requirements back in 1994. The final sample of regions in our study was restricted to those that had at least two foreign and domestic firms throughout the period of interest. Naturally there is a trade-off between this threshold and our sample size, as well as the bias towards foreign firms, when increasing it. Thus, the final sample consists of 75 microregions over 12 years yielding 900 region-year combinations.

\subsection{Indicators of export and import variety within ownership groups}

We opt for an ex ante measurement of relatedness, making use of the SITC classification system, because notwithstanding its limitations, this approach offers a consistent interpretation across regions (Blažek et al. 2016). Variety is quantified through entropy, by which one can measure the observable variety in a probability distribution (Frenken 2007). The entropy-measure takes its maximum value when productive activities have a uniform distribution over the classification, and entropy takes its minimum value when activities are concentrated in one of the classes. An attractive feature of the entropy-measure is its decomposability, as the total entropy of a distribution with several subclasses equals the sum of the average within class entropy and the between class entropy (Frenken 2007).

2321 HUF was equal to 1 EUR on 24 April 2019.

${ }^{3}$ As of 1 January 2014, the microregions seized to exist, and a new institutional-legal form was introduced (járás). The number of these units remained 175 . 
As we are particularly interested in whether the association between related trade variety and regional employment is structured by ownership, we apply this perspective on our independent variables. The variety measures described in Eqs. (1)-(6) are calculated separately for each ownership group, and subsequently denoted with a ' $D$ ' upper index for the subsample of domestic firms, while an ' $F$ ' upper index signifies a variety index calculated on the subsample of foreign firms.

The overall diversity of export activities in a region (VARIETY) can be calculated as the entropy of export product volumes at the 4-digit SITC level. Let $i=1, \ldots, N$ be a 4 -digit export product in a region. Let $p_{i}^{X}$ be the share of that export product $i$ in the export of the region. Then the total export variety can be calculated as:

$$
\text { VARIETY }=\sum_{i=1}^{N} p_{i}^{X} \log _{2}\left(\frac{1}{p_{i}^{X}}\right)
$$

A region with a diverse export portfolio has a high value of VARIETY as compared with a region with a specialised export portfolio. A positive link between VARIETY and regional employment would suggest the prevalence of inter-industry knowledge spillovers.

However, as discussed in the theoretical section, inter-industry spillovers can be expected when industries are technologically related. This is captured by the decomposition of the overall variety of the regional export portfolio into related and unrelated variety. The related variety of export (RELVAR) is the weighted average entropy of export volumes within 2-digit product classes. If every SITC 4-digit product $i$ falls under an SITC 2-digit product class $S_{g}$, where $g=1$, $\ldots, G$, then related variety is calculated as:

$$
R E L V A R=\sum_{g=1}^{G} P_{g}^{X} H_{g}^{X}
$$

where $P_{g}^{X}$ is the aggregation of the 4-digit export shares:

$$
P_{g}^{X}=\sum_{i e S_{g}} p_{i}^{X}
$$

The entropy within each 2-digit product class $S_{g}$ is $H_{g}^{X}$ :

$$
H_{g}^{X}=\sum_{i e S_{g}} \frac{p_{i}^{X}}{P_{g}^{X}} \log _{2}\left(\frac{1}{p_{i}^{X} / P_{g}^{X}}\right)
$$

Unrelated variety (UNRELVAR) is measured as the entropy of 2-digit export product volumes in a region:

$$
U N R E L V A R=\sum_{g=1}^{G} P_{g}^{X} \log _{2}\left(\frac{1}{P_{g}^{X}}\right)
$$

Finally, we calculate the import entropy at the 4-digit level (IMPVAR). Let $i=1, \ldots, N$ be a 4 digit import product in a region, and let $p_{i}^{I M}$ be the share of that 4-digit import product $i$ in the regional import volume. Then the total variety in import is: 


$$
I M P V A R=\sum_{i=1}^{N} p_{i}^{I M} \log _{2}\left(\frac{1}{p_{i}^{I M}}\right)
$$

\subsection{Indicators of related trade linkages within and between ownership groups}

The variables so far describe variety within ownership groups. However, it is just as important to measure relatedness between the foreign and domestic groups of firms in regions so as to capture spillovers between them. In order to do so, we calculated the average level of relatedness of export between foreign and domestic firms (RELFDIVAR) by adapting the measure of Boschma - Iammarino (2009) establishing the relatedness between import and export portfolios. Thus, RELFDIVAR measures for each 4 -digit product $(i=1$, $\ldots, N)$ exported by domestic firms the export entropy of foreign firms within the same 2digit class, excluding the 4 -digit product in question $\left(H_{i}^{F, X}\right)$. These cases are then weighted by the relative share of the same 4-digit export product in the export of domestic firms $\left(p_{i}^{D, X}\right)$ of the region. Finally, the weighted entropy values were aggregated at the regional level (Eq. 7).

$$
\text { RELFDIVAR }=\sum_{i=1}^{N} p_{i}^{D, X} H_{i}^{F, X}
$$

One must also account for the case, when the export activity of foreign firms is the same as the export activity of domestic firms in the region (FDISIM). A high value of the similarity indicator would suggest that productive knowledge is combined in less radical ways with lower value-added in the region. FDISIM is calculated as the product of the absolute values of export volumes of domestic $\left(X_{i}^{D}\right)$ and foreign firms $\left(X_{i}^{F}\right)$ for each 4 -digit product $(i=1, \ldots, N)$, aggregated at the regional level (Eq. 8).

$$
F D I S I M=\log \sum_{i=1}^{N} X_{i}^{D} X_{i}^{F}
$$

As for the relatedness of import and export, the related trade variety measure (RELTRAD$V A R)$ determines for each 4-digit import product $(i=1, \ldots, N)$ the import entropy within the same 2-digit class (by foreign or domestic firms), excluding the 4-digit product in question $\left(H_{i}^{I M}\right)$. These cases are then weighted by the relative share of the same 4-digit product in the export portfolio of either foreign or domestic firms $\left(p_{i}^{X}\right)$ of a given region. Finally, the weighted entropy values are aggregated at the regional level (Eq. 9).

$$
\text { RELTRADVAR }=\sum_{i=1}^{N} p_{i}^{X} H_{i}^{I M}
$$

The structuring dimensions of trade direction and firm ownership yield four different RELTRADVAR measures. For example, RELTRADVAR ${ }^{F D}$ measures the related import variety of foreign firms around export products of domestic firms, aggregated at the regional level. 
Just as before, the case of similarity between import and export products is accounted for by calculating ownership-sensitive trade similarity measures. For each ownership combination the similarity of trade as an indicator is determined by the product of the absolute values of regional import $\left(I M_{i}\right)$ and export $\left(X_{i}\right)$ volumes for each 4 -digit product $(i=1, \ldots, N)$, aggregated at the regional level (Eq. 10).

$$
\text { TRADESIM }=\log \sum_{i=1}^{N} X_{i} I M_{i}
$$

Applying the structuring dimension of ownership once again yields four variables. $T_{R A D E S I M}{ }^{F D}$, for example, measures the product of import by foreign firms and the export by domestic firms within the same 4-digit product classes aggregated at the regional level.

To lay out the relationship between the independent variables applied in this study, an overview is provided in Table 1.

\subsection{Estimation framework}

The dependent variable in this paper is regional employment within the domestic $\left(R E G E M P^{D}\right)$ and foreign $\left(R E G E M P^{F}\right)$ subset of exporting firms so as to get a more detailed insight on regional employment. A fixed-effect panel regression was chosen ${ }^{4}$ for estimation framework as this approach allows us to control for time-invariant unobserved heterogeneity across regions,

Table 1. Indicators of relatedness structured by ownership and direction of trade flow

\begin{tabular}{|c|c|c|c|}
\hline & Export not considered & Export by domestic firms & Export by foreign firms \\
\hline \multirow[t]{5}{*}{ Import not considered } & & VARIETY ${ }^{D}$ & VARIETY ${ }^{F}$ \\
\hline & & $R E L V A R^{D}$ & $R E L V A R^{F}$ \\
\hline & & UNRELVAR ${ }^{D}$ & UNRELVAR ${ }^{F}$ \\
\hline & & \multicolumn{2}{|c|}{ RELFDIVAR } \\
\hline & & \multicolumn{2}{|c|}{ FDISIM } \\
\hline \multirow[t]{2}{*}{ Import by domestic firms } & \multirow[t]{2}{*}{$I_{M P V A R^{D}}$} & RELTRADVAR ${ }^{D D}$ & RELTRADVAR \\
\hline & & TRADESIM ${ }^{D D}$ & TRADESIM ${ }^{D F}$ \\
\hline \multirow[t]{2}{*}{ Import by foreign firms } & \multirow[t]{2}{*}{$I M P V A R^{F}$} & RELTRADVAR ${ }^{F D}$ & RELTRADVAR ${ }^{F F}$ \\
\hline & & TRADESIM ${ }^{F D}$ & TRADESIM ${ }^{F F}$ \\
\hline
\end{tabular}

Notes: Single character upper indexes signify variables calculated within the domestic (' $D$ ') or foreign (' $F$ ') subset of firms; double character upper indexes signify direction of international trade, and ownership groups involved: the first character represents import (by foreign or domestic firms), while the second character represents export (by foreign or domestic firms).

\footnotetext{
${ }^{4}$ Hausman tests for the non-heteroskedasticity-robust estimations were applied to see whether the fixed-effect or random-effect models are more adequate. Based on the overall $\chi^{2}$ statistic in each model, we concluded that the random effect models are not appropriate for our analysis.
} 
such as institutions (Cameron - Trivendi 2009), while also reducing the risk of endogeneity. Moreover, compared to the cross-sectional models where the between-effect is emphasised, the within estimator of the fixed-effect model allows us to model the changes in employment in one region in relation to the changes in the explanatory variables over time in that particular region. We estimated the following equation:

$$
Y_{i t}=\beta X_{i t-1}+\gamma C_{i t-1}+u_{i}+\varepsilon_{i t}
$$

where $Y_{i t}$ is the level of the dependent variable in region $i$ at time $t, X_{i t-1}$ is the vector of the region-specific independent variables at time $t-1, C_{i t-1}$ is the vector of the control variables at time $t-1, u_{i}$ is the region-specific fixed-effect and $\varepsilon_{i t}$ is the error term. By having all explanatory variables measured the year before the dependent variable, we reduce the risk of reversed causality influencing the results.

Positive coefficients of the variety measures in the fixed-effect approach mean that an above average level of variety in the region in $t-1$ is associated with an above average level of employment in the region in $t$. The entropy-based measures of variety in the export product portfolio can increase in two ways: by the diminishing export volume of products with large export shares or by the growing shares of products with low export weights. Because one can expect that decaying export leads to a decrease in employment later on, we can argue that the gradual development of trade variety leads to higher than average employment levels through the rise of related or unrelated export products. In this paper, rather than estimating a regional growth model, we aim to show that certain types of trade varieties in the region are linked to higher employment compared with other types of trade varieties.

While variety levels are changing slowly on the short-run, the independent variables show sufficient within variation. As the Hungarian spatial structure is extremely skewed, i.e. Budapest, the capital, holds $20-25 \%$ of total employees in export and total export volume, ${ }^{5}$ we use the decimal logarithm of the dependent, as well as control variables. We rely on the following regional level controls. First, urbanisation economies are controlled for by population density (POPDENS), as it is commonly used in economic geography. We attempt to control for the effect of intra-industry spillovers and localisation economies with the Herfindahl-Hirschman concentration index $(H H I)$ of employment at the 4-digit NACE level in the regional portfolio. A high $H H I$ value would suggest higher endowment in labour force for a few industries only. The average number of employees of firms (AVGSIZE) is used to control for employment differences by firm size. Finally, gross investments (INVEST) are used as a regional control variable of new ventures either increasing employment through the use of additional labour input, or decreasing it through the replacement of labour by capital input.

All control variables, with the exception of urban size, are split into the categories of foreign and domestic ownership so as to fit the logic of differentiating between these groups of firms. This way we can use the controls in a more refined way, as they are likely to be different in the cases of foreign and domestic firms (e.g. average firm size in the foreign group of firms is higher in general compared with the domestic case). In the vast majority of cases the pairwise correlation of covariates is below 0.6, and the variance inflation factor (VIF) values of the

\footnotetext{
${ }^{5}$ We ran our models omitting the capital region, because its weight in the Hungarian economy, however leaving Budapest out of the sample did not change the results.
} 
multicollinearity statistics ${ }^{6}$ are below 5 in all models reported below, therefore no issues of multicollinearity are expected.

\section{RESULTS}

Most of the international trade in Hungary can be attributed to foreign firms, especially in manufacturing. These firms are the drivers of export growth (Holland et al. 2000; Sass 2003). Further evidence based on Hungarian data shows that foreign firms use imported inputs more effectively than domestic companies (Halpern et al. 2015), and that trading firms benefit more from agglomeration economies than non-trading firms (Békés - Harasztosi 2013). The divide between foreign and domestic manufacturing export widened between 2000 and 2012. The number of employees in foreign manufacturing exporter firms was 350,000 in 2000, which fell to 260,000 by 2012 (Fig. 1A). One can observe a much sharper decrease in the case of domestic companies: the number of employees fell from 250,000 to 130,000. However, the foreign-domestic gap is even more pronounced when it comes to international trade flow values; the volume of export by foreign firms increased sharply over the period in question and exceeded import significantly, which was hardly the case for domestic companies (Fig. 1B). Major trends of Hungarian trade in the period of our investigation indicate that the divide between manufacturing export of foreign and domestic firms widened, and foreign companies were more likely to combine imported inputs and re-export, compared with domestic firms (Fig. 1C). The increase of export by foreign firms in the regions also increased the employment of these companies more than the export by domestic firms increased employment in domestic companies (Fig. 1D).

Turning to the regression results, Table 2 reports our findings on the association between regional employment and relatedness in export, while the results on related trade linkages are reported in Table 3. All models are statistically significant based on the F-statistic at the 0.01 level. The control variables indicate plausible relations: the concentration of the employment of domestic firms in fewer industries $\left(H H I^{D}\right)$ shows a negative correlation with employment, indicating that a more specialised regional portfolio of employment in the host economy goes hand in hand with decreased opportunities for establishing new market niches. Similar relation does not appear when it comes to the concentration of employment in foreign firms $\left(H H I^{F}\right)$. The controls on average firm size (AVGSIZE) indicate that a higher number of larger firms in a region means higher employment for the same ownership group. Additionally, an increase in the average size of foreign firms $\left(A V G S I Z E^{F}\right)$ is associated negatively with the employment potential of domestic firms suggesting competition for workforce between the groups. Finally, investments by foreign firms (INVEST ${ }^{F}$ ) are positively associated with the employment of foreign firms, while negatively with the employment of domestic firms. This is pointing towards that the investment activities of foreign firms in particular are followed by an increase in demand for labour input, most likely putting pressure on domestic firms already in the region. Investments in the domestic group $\left(\right.$ INVEST $\left.^{D}\right)$ also have a negative correlation with the employment of foreign firms, but with lower level of significance.

\footnotetext{
${ }^{6}$ VIF measures the linear association between an independent variable and all the other independent variables. A VIF value of higher than 5 warrants further investigation, and a value of higher than 10 indicates a high chance of multicollinearity (Rogerson 2001).
} 
(A)

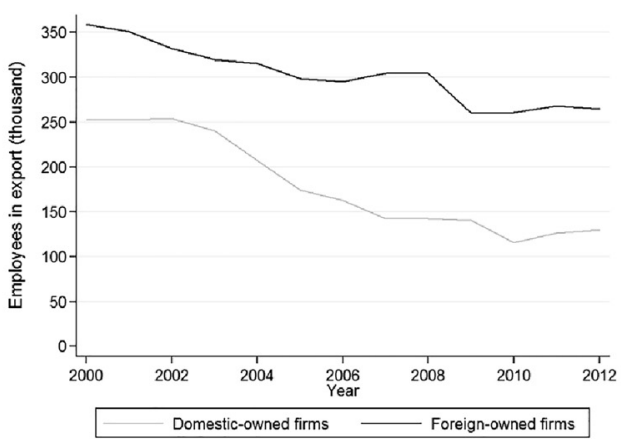

(C)

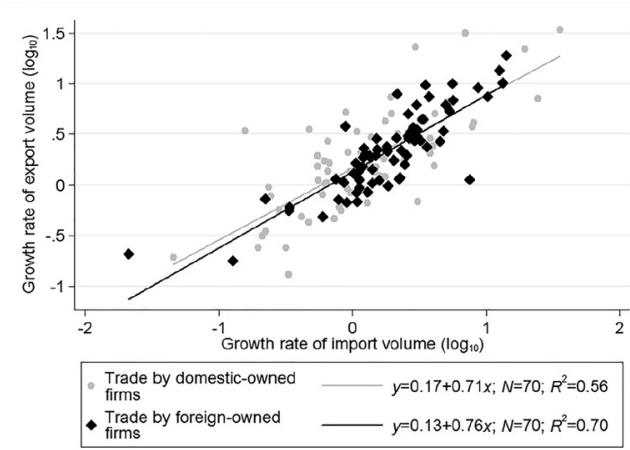

(B)

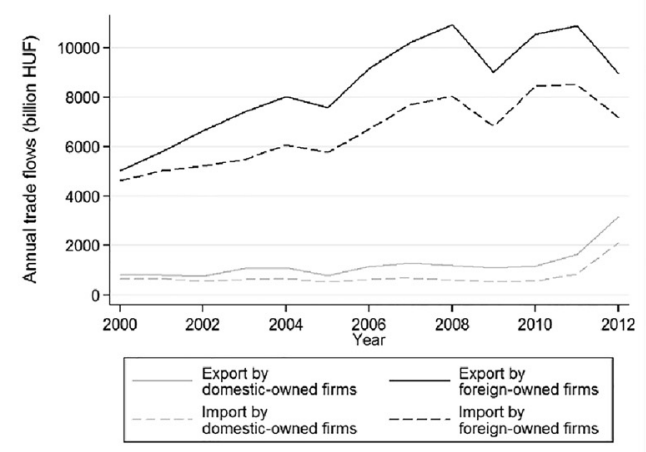

(D)

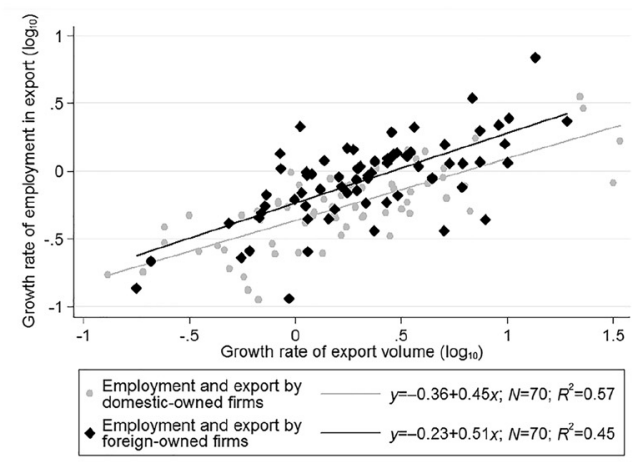

Fig. 1. International trade and employment in foreign and domestic firms, 2000-2012

Source: Own construction based on the data described in the empirical section. Notes: (A) Total annual employment in manufacturing export (thousand employees) by foreign and domestic companies. (B) Total annual export and import in manufacturing (billion HUF) by foreign and domestic companies. (C) Correlation of import and export growth in foreign and domestic companies at the regional level. (D) Correlation of employment and export growth in foreign and domestic companies at the regional level. Grey lines and circles represent the regional aggregates of domestic companies, black lines and diamonds represent the aggregates of foreign companies. The solid lines of graphs (C) and (D) represent a linear estimation.

Models 1 and 2 in Table 2 indicate that a higher export variety of domestic firms (VARI$E T Y^{D}$ ) yields additional employment in both the domestic and the foreign set of firms. This means that a more versatile regional portfolio of export products produced by the host economy translates into higher employment in export, spilling over even to foreign firms. While the latter seems surprising, Models 3 and 4 shed some light on why this might be the case. In these models the overall export variety is decomposed into related and unrelated variety within each ownership group, as well as to the relatedness between them. One can observe in Model 3 that it is the related variety within the domestic group of firms $\left(R E L V A R^{D}\right)$ in particular, that is positively associated with employment in the host economy. Following the theoretical 
Table 2. The relationship between related variety of export and employment in export activities in the Hungarian microregions between 2000 and 2011

\begin{tabular}{|c|c|c|c|c|}
\hline & $\begin{array}{c}(1) \\
\text { Domestic }\end{array}$ & $\begin{array}{c}(2) \\
\text { Foreign }\end{array}$ & $\begin{array}{c}(3) \\
\text { Domestic }\end{array}$ & $\begin{array}{c}\text { (4) } \\
\text { Foreign }\end{array}$ \\
\hline \multirow[t]{2}{*}{$\log P O P D E N S_{t-1}$} & 0.200 & -0.105 & 0.054 & -0.111 \\
\hline & $(0.31)$ & $(-0.32)$ & $(0.08)$ & $(-0.33)$ \\
\hline \multirow[t]{2}{*}{$\log H H I_{t-1}^{D}$} & $-0.152 * * *$ & $-0.060 * *$ & $-0.142 * * *$ & $-0.059 * *$ \\
\hline & $(-3.40)$ & $(-2.12)$ & $(-3.45)$ & $(-2.22)$ \\
\hline \multirow[t]{2}{*}{$\log H H_{t-1}^{F}$} & -0.035 & -0.044 & -0.037 & -0.048 \\
\hline & $(-0.48)$ & $(-1.47)$ & $(-0.52)$ & $(-1.50)$ \\
\hline \multirow[t]{2}{*}{$\log A V G S I Z E_{t-1}^{D}$} & $0.292 * * *$ & 0.049 & $0.270 * * *$ & 0.048 \\
\hline & (3.52) & $(1.57)$ & (3.41) & $(1.50)$ \\
\hline \multirow[t]{2}{*}{$\log A V G S I Z E_{t-1}^{F}$} & $-0.117^{*}$ & $0.395^{* * *}$ & $-0.134 * *$ & $0.392 * * *$ \\
\hline & $(-1.74)$ & $(10.08)$ & $(-2.13)$ & $(10.11)$ \\
\hline \multirow[t]{2}{*}{$\log I N V E S T_{t-1}^{D}$} & -0.010 & $-0.036 *$ & -0.010 & $-0.036 *$ \\
\hline & $(-0.43)$ & $(-1.70)$ & $(-0.43)$ & $(-1.69)$ \\
\hline \multirow[t]{2}{*}{$\log I N V E S T_{t-1}^{F}$} & $-0.083^{* *}$ & $0.059 * *$ & $-0.069 *$ & $0.060 * *$ \\
\hline & $(-2.34)$ & $(2.30)$ & $(-1.89)$ & $(2.33)$ \\
\hline \multirow[t]{2}{*}{ VARIETY $Y_{t-1}^{D}$} & $0.110 * *$ & $0.076 * * *$ & & \\
\hline & $(2.37)$ & (2.95) & & \\
\hline \multirow[t]{2}{*}{ VARIETY $_{t-1}^{F}$} & 0.058 & 0.029 & & \\
\hline & $(0.98)$ & $(1.08)$ & & \\
\hline \multirow[t]{2}{*}{$R^{\prime} E L V A R_{t-1}^{D}$} & & & $0.110 * * *$ & $0.035^{* *}$ \\
\hline & & & $(4.32)$ & $(2.34)$ \\
\hline \multirow[t]{2}{*}{$R^{\prime} E L V A R_{t-1}^{F}$} & & & 0.060 & 0.026 \\
\hline & & & $(1.58)$ & $(1.10)$ \\
\hline \multirow[t]{2}{*}{$U_{N R E L V A R}^{D}$} & & & 0.032 & $0.058^{* *}$ \\
\hline & & & $(0.66)$ & $(2.40)$ \\
\hline \multirow[t]{2}{*}{$U_{N R E L V A R}^{F}$} & & & -0.001 & 0.013 \\
\hline & & & $(-0.01)$ & $(0.51)$ \\
\hline \multirow[t]{2}{*}{$R_{E L F D I V A R} R_{t-1}$} & & & 0.038 & -0.000 \\
\hline & & & (1.15) & $(-0.01)$ \\
\hline FDISIM $_{t-1}$ & & & $0.047^{* *}$ & 0.003 \\
\hline
\end{tabular}


Table 2. Continued

\begin{tabular}{|l|c|c|c|c|}
\hline & $\begin{array}{c}(\mathbf{1}) \\
\text { Domestic }\end{array}$ & $\begin{array}{c}\text { (2) } \\
\text { Foreign }\end{array}$ & $\begin{array}{c}\text { (3) } \\
\text { Domestic }\end{array}$ & $\begin{array}{c}\text { (4) } \\
\text { Foreign }\end{array}$ \\
\hline \# of observations & & & $(2.27)$ & $(0.14)$ \\
\hline \# of regions & 825 & 825 & 825 & 825 \\
\hline R-squared & 75 & 75 & 75 & 75 \\
\hline Adj. -squared & 0.221 & 0.373 & 0.245 & 0.374 \\
\hline F & 0.212 & 0.366 & 0.233 & 0.364 \\
\hline Sig. & 5.98 & 18.37 & 8.06 & 14.48 \\
\hline
\end{tabular}

Notes: Standardised beta coefficients; t-statistics in parentheses;

$* P<0.10, * * P<0.05, * * * P<0.01$.

argumentation behind related variety, this suggests to us that spillovers are at play between the related industries of domestic firms. As for the spillovers from the foreign group of firms, Model 3 shows that neither relatedness within the foreign group $\left(R E L V A R^{F}\right)$, nor its relatedness to the domestic group (RELFDIVAR) has a link to increased employment in the host economy. Interestingly, it is the similarity of export activities by domestic and foreign firms (FDISIM) that is positively correlated with employment potential. What follows is that higher levels of technological proximity, represented by similarity in our operationalisation, are required for exporting domestic firms to benefit from the presence of exporting foreign firms. Therefore, the combination of more similar, rather than related products is what favours future employment.

This finding is reasonable considering Hungarian manufacturing export relied heavily on the low value-added assembling activities in the period of our investigation (Nölke - Vliegenthart 2009). It is worth noting though, that in this paper we focus on the structure of economic activities in the regions, but not the content of these activities. Evidence in the literature suggests that domestic firms are more likely to introduce more complex products when they supply foreign affiliates (Javorcik et al. 2018), and upgrading in a number of industries and business processes is under way in Hungary (Sass - Szalavetz 2014). Based on these arguments we would expect the similarity measure to gradually give place to the related trade variety measure over time, however we cannot test this expectation with the data at hand.

Model 4 of Table 2 offers insights on foreign firms in particular. The decomposition of variety illuminates that the benefits of variety in the domestic group $\left(V_{\text {VARIETY }}{ }^{\mathrm{D}}\right.$ ) are largely coming from the unrelated variety within the domestic group (UNRELVAR ${ }^{\mathrm{D}}$ ), and partially from the related activities within this group $\left(\right.$ RELVAR $\left.^{\mathrm{D}}\right)$. The former may be due to the fact that a more heterogeneous industry profile offers a wider range of resources for foreign firms to exploit. The latter suggests that spillovers within the host economy - while being beneficial for domestic firms - also signal development in the local economic conditions surrounding foreign firms.

In Table 3 we turn to our models on import and the relatedness in trade linkages. Models 1 and 2 present the results on import variety for each ownership group, while these results are decomposed to relatedness (or similarity) between import and export activities in Models 3-6. 
Table 3. The relationship between related trade variety and employment in export activities in the Hungarian microregions between 2000 and 2011

\begin{tabular}{|c|c|c|c|c|c|c|}
\hline & $\begin{array}{c}\text { (1) } \\
\text { Domestic }\end{array}$ & $\begin{array}{c}\text { (2) } \\
\text { Foreign }\end{array}$ & $\begin{array}{c}\text { (3) } \\
\text { Domestic }\end{array}$ & $\begin{array}{c}\text { (4) } \\
\text { Domestic }\end{array}$ & $\begin{array}{c}(5) \\
\text { Foreign }\end{array}$ & $\begin{array}{c}(6) \\
\text { Foreign }\end{array}$ \\
\hline \multirow[t]{2}{*}{$\log P O P D E N S_{t-1}$} & 0.039 & -0.199 & -0.025 & 0.217 & -0.157 & -0.218 \\
\hline & $(0.08)$ & $(-0.69)$ & $(-0.04)$ & $(0.36)$ & $(-0.50)$ & $(-0.71)$ \\
\hline \multirow{2}{*}{$\log H H I_{t-1}^{D}$} & $-0.130 * *$ & $-0.076 * * *$ & $-0.153 * * *$ & $-0.191 * * *$ & $-0.083^{* * *}$ & $-0.097 * * *$ \\
\hline & $(-2.64)$ & $(-2.75)$ & $(-3.25)$ & $(-3.82)$ & $(-2.83)$ & $(-3.53)$ \\
\hline \multirow[t]{2}{*}{$\log \mathrm{HHI}_{t-1}^{F}$} & -0.070 & $-0.058 *$ & -0.080 & -0.063 & $-0.062 *$ & -0.053 \\
\hline & $(-1.10)$ & $(-1.75)$ & $(-1.28)$ & $(-0.96)$ & $(-1.89)$ & $(-1.58)$ \\
\hline \multirow[t]{2}{*}{$\log A V G S I Z E_{t-1}^{D}$} & $0.297 * * *$ & $0.058^{*}$ & $0.245 * * *$ & $0.292 * * *$ & 0.048 & $0.055^{*}$ \\
\hline & $(3.51)$ & $(1.82)$ & $(2.87)$ & $(3.36)$ & $(1.36)$ & $(1.69)$ \\
\hline \multirow[t]{2}{*}{$\log A V G S I Z E_{t-1}^{F}$} & -0.067 & $0.406 * * *$ & -0.097 & -0.064 & $0.393 * * *$ & $0.377^{* * *}$ \\
\hline & $(-1.02)$ & $(10.29)$ & $(-1.49)$ & $(-0.91)$ & $(9.71)$ & $(8.07)$ \\
\hline \multirow[t]{2}{*}{$\log I N V E S T_{t-1}^{D}$} & -0.001 & $-0.033^{*}$ & -0.018 & -0.008 & $-0.033^{*}$ & $-0.032^{*}$ \\
\hline & $(-0.03)$ & $(-1.78)$ & $(-0.75)$ & $(-0.34)$ & $(-1.70)$ & $(-1.67)$ \\
\hline \multirow[t]{2}{*}{$\log I N V E S T_{t-1}^{F}$} & $-0.076^{* *}$ & $0.060^{* *}$ & $-0.080^{* *}$ & $-0.073^{*}$ & $0.061^{* *}$ & $0.050^{* *}$ \\
\hline & $(-2.14)$ & (2.31) & $(-2.41)$ & $(-1.98)$ & $(2.26)$ & $(2.26)$ \\
\hline \multirow[t]{2}{*}{$I M P V A R_{t-1}^{D}$} & $0.183^{* * *}$ & $0.051 * *$ & & & & \\
\hline & $(5.25)$ & (2.51) & & & & \\
\hline \multirow[t]{2}{*}{$I M P V A R_{t-1}^{F}$} & $0.116 * * *$ & $0.049 * * *$ & & & & \\
\hline & $(2.99)$ & $(2.65)$ & & & & \\
\hline \multirow[t]{2}{*}{ 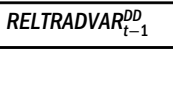 } & & & $0.103 * * *$ & & $0.054 * * *$ & \\
\hline & & & $(3.23)$ & & (3.40) & \\
\hline \multirow[t]{2}{*}{ RELTRADVAR ${ }_{t-1}^{D F}$} & & & $0.077^{* *}$ & & 0.010 & \\
\hline & & & $(2.25)$ & & $(0.57)$ & \\
\hline \multirow[t]{2}{*}{ TRADESIM ${ }_{t-1}^{D D}$} & & & $0.045^{*}$ & & $-0.031^{* * *}$ & \\
\hline & & & $(1.82)$ & & $(-2.83)$ & \\
\hline \multirow[t]{2}{*}{ TRADESIM ${ }_{t-1}^{D F}$} & & & 0.028 & & 0.016 & \\
\hline & & & $(1.02)$ & & $(0.77)$ & \\
\hline \multirow[t]{2}{*}{ RELTRADVAR $_{t-1}^{F F}$} & & & & 0.057 & & $0.050 * * *$ \\
\hline & & & & $(1.48)$ & & $(3.07)$ \\
\hline \multirow[t]{2}{*}{ RELTRADVAR $_{t-1}^{F D}$} & & & & 0.022 & & 0.013 \\
\hline & & & & $(0.76)$ & & $(0.99)$ \\
\hline \multirow[t]{2}{*}{ TRADESIM $_{t-1}^{F F}$} & & & & $-0.179 * * *$ & & 0.032 \\
\hline & & & & $(-3.03)$ & & $(0.77)$ \\
\hline \multirow[t]{2}{*}{ TRADESIM ${ }_{t-1}^{F D}$} & & & & $0.059 * *$ & & 0.009 \\
\hline & & & & $(2.28)$ & & $(0.59)$ \\
\hline$\#$ of observations & 825 & 825 & 825 & 825 & 825 & 825 \\
\hline \# of regions & 75 & 75 & 75 & 75 & 75 & 75 \\
\hline$R$-squared & 0.278 & 0.372 & 0.254 & 0.236 & 0.373 & 0.369 \\
\hline
\end{tabular}


Table 3. Continued

\begin{tabular}{|l|c|c|c|c|c|c|}
\hline & $\begin{array}{c}(\mathbf{1}) \\
\text { Domestic }\end{array}$ & $\begin{array}{c}(\mathbf{2}) \\
\text { Foreign }\end{array}$ & $\begin{array}{c}\mathbf{( 3 )} \\
\text { Domestic }\end{array}$ & $\begin{array}{c}\mathbf{( 4 )} \\
\text { Domestic }\end{array}$ & $\begin{array}{c}\mathbf{( 5 )} \\
\text { Foreign }\end{array}$ & $\begin{array}{c}\mathbf{( 6 )} \\
\text { Foreign }\end{array}$ \\
\hline Adj. -squared & 0.270 & 0.366 & 0.244 & 0.226 & 0.364 & 0.360 \\
\hline F & 9.78 & 21.62 & 10.37 & 8.39 & 17.65 & 16.85 \\
\hline Sig. & $0.0000^{* * *}$ & $0.0000^{* * *}$ & $0.0000^{* * *}$ & $0.0000^{* * *}$ & $0.0000^{* * *}$ & $0.0000^{* * *}$ \\
\hline
\end{tabular}

Notes: Standardised beta coefficients; t-statistics in parentheses;

$* P<0.10, * * P<0.05, * * * P<0.01$.

The first observation one can make based on Model 1 and 2 of Table 3 is that the variety of import (IMPVAR) is positively correlated with regional employment in manufacturing export. This does not come as a surprise since export success often goes hand in hand with a considerable import component (Békés et al. 2013). As for ownership, the coefficient of import variety within the domestic group (IMPVAR ${ }^{\mathrm{D}}$ ) surpasses that of the foreign group (IMPVAR ${ }^{\mathrm{F}}$ ) in Model 1, indicating that domestic export firms benefit from an above average level of import especially when it is channelled through the host economy. Additionally, as the coefficient of import variety within the foreign group $\left(\mathrm{IMPVAR}^{\mathrm{F}}\right.$ ) is positive and significant, domestic firms benefit from the presence of foreign firms through spillovers. Interestingly, Model 2 of Table 3 adds that the employment of foreign firms also increases with the increase in import variety, however there is barely any difference between the coefficients of import variety within the ownership groups (IMPVAR ${ }^{\mathrm{D}}$ and $\mathrm{IMPVAR}^{\mathrm{F}}$ ). Coupled with the lack of association between the employment of foreign firms, and the related variety of their export activities (RELVAR ${ }^{\mathrm{F}}$ ) previously described, this suggests that for foreign firms the primary source of spillovers within the group is linked to importing.

To further develop these findings, we next look at domestic firms in Models 3 and 4 of Table 3. Most strikingly, we find that the relatedness of import and export only matters for employment when domestic firms are the ones who import: the coefficients of both RELTRADVAR ${ }^{D D}$ and RELTRADVAR $^{\mathrm{DF}}$ are positive and significant, while RELTRADVAR ${ }^{F F}$ and RELTRADVAR ${ }^{F D}$ are not significant. Coupled with the coefficients of the similarity indicators in Models 3 and 4, this shows us that the host economy benefits from foreign firms importing primarily when it is in similar products as the export of domestic firms $\left(T R A D E S I M^{F D}\right)$, suggesting low value-added. The negative coefficient of TRADESIM ${ }^{F F}$ in Model 4 represents the case when foreign firms import as well as export within the same product class, most likely crowding out domestic firms.

To sum up these results, import as a channel for extra-regional knowledge is more likely to help the host economy if domestic firms partake in it. Import may increase the absorptive capacity of domestic firms, as well as increase the probability of knowledge spillovers. In addition to that, this channel is operational in weaker technological proximity as opposed to the case when foreign firms import. In the latter case, similarity (much stronger relatedness) is required for the host economy to benefit from the import of foreign firms. As most of the inputs have to be imported in a small and open economy such as Hungary (Halpern et al. 2015), import seems to be a major source of potential spillovers for the host economy, even between foreign and domestic firms, but certainly structured by different degrees of technological relatedness.

As for foreign firms, Models 5 and 6 of Table 3 suggest that they benefit from import when it is related to the export of foreign companies (RELTRADVAR ${ }^{F F}$ ), while similarity of trade has no 
significant effect on their employment, with the exception of import and export both performed by domestic firms (TRADESIM ${ }^{D D}$ ). This shows that foreign firms can benefit from horizontal spillovers within this ownership group without the necessity for strong technological relatedness (similarity). The negative coefficient of TRADESIM ${ }^{D D}$ may once again be due to increased competition, and a crowding-out of value-chains, this time by domestic firms. Interestingly, the related trade linkages of domestic firms (RELTRADVAR ${ }^{D D}$ ) are positively associated with the employment of foreign firms, pointing out that the source of a positive $I M P V A R^{D}$ coefficient in Model 2 may be due to the increase of these linkages in the host economy.

\section{CONCLUSIONS}

In this paper we have set out to reveal the association between the technological relatedness of trade activities by foreign and domestic firms, and the level of employment in regions. To do so, we relied on a panel of Hungarian microregions between 2000 and 2011 based on register-type data by using a fixed-effect panel regression approach. We see three main conclusions to be drawn from the results.

First, the host economy benefits from the relatedness of export activities when it is within the domestic group of firms. Based on the arguments behind related variety, this means that domestic export firms have a potential to learn from each other. Additionally, it was revealed from the results that participating in international value-chains as importers yields additional employment later on for domestic firms, pointing out that import is a crucial channel for learning for the host economy. This shows that in the case of small and open economies where a substantial portion of inputs have to be imported, learning by importing is indeed a spillover mechanism for domestic firms.

Second, to bridge the technological gap between foreign and domestic firms, and for the host economy to benefit from the presence of foreign firms, stronger technological proximity may be required. This finding supports the idea that foreign firms at the time offered opportunities for the host regions to be involved mostly in low value-added assembly activities in manufacturing in CEE countries. It remains to be seen how introducing more complex products and gradual upgrading are shaping these patters. Similarly, if foreign firms do the importing, domestic firms benefit from international trade linkages if technological relatedness is stronger. Interestingly, even this duality can somewhat be mitigated by experience through import gained by domestic firms, in which case weaker technological proximity can be bridged between foreign firms and the host economy. These observations, matching evidence from case studies of industries dominated by MNEs (e.g. Šipikal - Buček 2013), indicate that foreign firms offer more incremental learning opportunities for the host regions in a CEE context. That is unless domestic firms themselves can improve upon their absorptive capacity by gaining experience in international markets and upgrading.

Third, relatedness in the host economy offers benefits for foreign firms as well. One of these is the development of the business environment through related variety within the domestic group. Another is that apparently foreign firms also find the unrelated variety of domestic activities to be of use. As unrelated variety means a more diverse set of industry-specific resources in the regions, foreign firms may find more opportunities to rearrange these resources to their needs. Coupled with the observation that relatedness within the foreign subset of exporters 
does not offer opportunities for horizontal spillovers for foreign firms, this leads us to argue that foreign firms may seek resources other than learning opportunities from others when operating in a dependent market economy. This seems plausible as MNEs learning routines are often driven from the home base of these companies, outside the host economy (Nölke - Vliegenthart 2009). However, our results also indicate that import serves as a channel for novelty within this group of firms, meaning that spillovers through related trade linkages, rather than horizontal spillovers between export activities, are a non-negligible mechanism for learning within this group of firms.

Based on these findings our policy recommendation is not to neglect the opportunities of spillovers between domestic firms as this is a channel for learning for the host economy. Additionally, notwithstanding that integrating domestic firms into global value chains is not a silver bullet for upgrading for all industries, we would also suggest aiding domestic firms to access international markets and opportunities for learning by importing as part of the valuechains of foreign firms. As demonstrated in this paper, doing so would render domestic firms more capable of absorbing novelty from foreign firms. Consequently, there would also be merit in enhancing the embeddedness of foreign firms in the economies of regions, as well as foster networking between domestic firms to actuate the potential in related trade linkages explored in this study.

\section{ACKNOWLEDGEMENT}

We thank Jiří Blažek, Ron Boschma, Imre Lengyel, László Szerb and Attila Varga for their suggestions. Szakálné Izabella Kanó, Balázs Kotosz and László Czaller provided further help. Useful comments have been received at the Annual Conference of the Hungarian Regional Science Association, the 2nd workshop on 'Evolutionary Economic Geography in Central and Eastern Europe in 2015', the 6th Slovak Winter Seminar of Regional Science in 2016, and the 1st Early Career Paper Seminar in Regional Science in 2016. Zoltán Elekes acknowledges the financial support of the New National Excellence Program of the Ministry of Human Capacities of the Hungarian Government (Grant ID: UNKP-17-3-III-SZTE-10).

\section{REFERENCES}

Aitken, B. - Hanson, G. H. - Harrison, A. E. (1997): Spillovers, Foreign Investment, and Export Behaviour. Journal of International Economics, 43(1-2): 103-132.

Antalóczy, K. (2012): Beágyazódás a globális értékláncokba - két évtized külkereskedelmi folyamatai Magyarországon (Two Decades of Hungarian Foreign Trade - Embedded in Global Value Chains). Külgazdaság, 56(11-12): 29-61.

Awokuse, T. O. (2008): Trade Openness and Economic Growth: Is Growth Export-Led or Import-Led?. Applied Economics, 40(2): 161-173.

Barta, Gy. (2005): The Role of Foreign Direct Investment in the Spatial Restructuring of Hungarian Industry. In: Barta, Gy. - Fekete, É. G. - Szörényiné, Kukorelli. I. - Timár, J. (eds): Hungarian Spaces and Places: Patterns of Transition. Pécs: Centre for Regional Studies, pp. 143-160. 
Beaudry, C. - Schiffauerova, A. (2009): Who's Right, Marshall or Jacobs? The Localization versus Urbanization Debate. Research Policy, 38(2): 318-337.

Békés, G. - Harasztosi, P. (2013): Agglomeration Premium and Trading Activity of Firms. Regional Science and Urban Economics, 43(1): 51-64.

Békés, G. - Halpern, L. - Muraközy, B. (2013): A külkereskedelem és a vállalatok közötti különbségek (Heterogeneous Firms and Foreign Trade). Közgazdasági Szemle, LX(January): 1-24.

Békés, G. - Kleinert, J. - Toubal, F. (2009): Spillovers from Multinationals to Heterogeneous Domestic Firms: Evidence from Hungary. The World Economy, 32(10): 1408-1433.

Beugelsdijk, S. - Mccann, P. - Mudambi, R. (2010): Introduction: Place, Space and Organization-Economic Geography and the Multinational Enterprise. Journal of Economic Geography, 10(4): 485-493.

Blažek, J. - Marek, D. - Květoň, V. (2016): The Variety of Related Variety Studies: Opening the Black Box of Technological Relatedness via Analysis of Inter-Firm R\&D Cooperative Projects. Papers in Evolutionary Economic Geography, No. 1611. University Utrecht, Faculty of Geosciences.

Boschma, R. (2005): Proximity and Innovation: A Critical Assessment. Regional Studies, 39(1): 61-74.

Boschma, R. - Iammarino, S. (2009): Related Variety, Trade Linkages, and Regional Growth in Italy. Economic Geography, 85(3): 289-311.

Brülhart, M. (1998): Economic Geography, Industry Location and Trade: The Evidence. The World Economy, 21(6): 775-801.

Cameron, A. C. - Trivendi, P. K. (2009): Microeconometrics Using Stata. College Station, Texas: Stata Press.

Caragliu, A. - De Dominicis, L. - De Groot, H. L. F. (2016): Both Marshall and Jacobs were Right! Economic Geography, 92(1): 87-111.

Content, J. - Frenken, K. (2016): Related Variety and Economic Development: A Literature Review. European Planning Studies, 24(12): 2097-2112.

Cortinovis, N. - Crescenzi, R. - Van Oort, F. (2020): Multinational Enterprises, Industrial Relatedness and Employment in European Regions. Journal of Economic Geography, 20(5): 1165-1205.

Csáfordi, Zs. - Lőrincz, L. - Lengyel, B. - Kiss, K. M. (2020): Productivity Spillovers through Labor Flows: Productivity Gap, Multinational Experience and Industry Relatedness. The Journal of Technology Transfer, 45(1): 86-121.

Csiki, O. - Horváth, R. - Szász, L. (2019): A Study of Regional-Level Location Decision Factors in the Automotive Industry of the EU. Acta Oeconomica, 69(S): 11-37.

Damijan, J. P. - Kostevc, Č. (2010): Learning from Trade through Innovation: Causal Link between Imports, Exports and Innovation in Spanish Microdata. LI COS Discussion Paper, No. 26410.

Dicken, P. (1994): The Roepke Lecture in Economic Geography. Global-Local Tensions: Firms and States in the Global Space-Economy. Economic Geography, 70(2): 101-128.

Frenken, K. (2007): Entropy Statistics and Information Theory. In: Hanusch, H. - Pyka, A. (eds): Elgar Companion to Neo-Schumpeterian Economics. Cheltenham - Northampton: Edward Elgar, pp. 544-555.

Frenken, K. - Van Oort, F. - Verburg, T. (2007): Related Variety, Unrelated Variety and Regional Economic Growth. Regional Studies, 41(5): 685-697.

Glaeser, E. - Kallal, H. D. - Scheinkman, J. D. - Shleifer, A. (1992): Growth in Cities. Journal of Political Economy, 100(6): 1126-1152.

Görg, H. - Greenaway, D. (2004): Much Ado about Nothing? Do Domestic Firms Really Benefit from Foreign Direct Investment?. The World Bank Research Observer, 19(2): 171-198.

Greeneway, D. - Keller, R. (2007): Firm Heterogeneity, Exporting and Foreign Direct Investment. The Economic Journal, 117(517): F134-F161. 
Halpern, L. - Muraközy, B. (2007): Does Distance Matter in Spillover?. Economics of Transition, 15(4): 781-805.

Halpern, L. - Muraközy, B. (2010): Innováció és vállalati teljesítmény Magyarországon (Innovation and Company Performance in Hungary). Közgazdasági Szemle, LVII(April): 293-317.

Halpern, L. - Koren, M. - Szeidl, A. (2015): Imported Inputs and Productivity. American Economic Review, 105(12): 3660-3703.

Haskel, J. E. - Pereira, S. C. - Slaughter, M. J. (2007): Does Inward Foreign Direct Investment Boost the Productivity of Domestic Firms?. The Review of Economics and Statistics, 89(3): 482-496.

Henderson, J. V. - Kuncoro, A. - Turner, M. (1995): Industrial Development in Cities. Journal of Political Economy, 103(5): 1067-1085.

Hidalgo, C. A. - Balland, P-A. - Boschma, R. - Delgado, M. - Feldman, M. - Frenken, K. - Glaeser, E. He, C. - Kogler, D. F. - Morrison, A. - Neffke, F. - Rigby, D. - Stern, S. - Zheng, S. - Zhu, S. (2018): The Principle of Relatedness. In: Morales, A. - Gershenson, C. - Braha, D. - Minai, A. - Bar-Yam, Y. (eds): Unifying Themes in Complex Systems IX. ICCS 2018. Springer Proceedings in Complexity. Springer, pp. 451-457.

Holland, D. - Sass, M. - Benacek, V. - Gronicki, M. (2000): The Determinants and Impact of FDI in Central and Eastern Europe: A Comparison of Survey and Econometric Evidence. Transnational Corporations, 9(3): 163-212.

Iammarino, S. - McCann, P. (2013): Multinationals and Economic Geography. Cheltenham - Northampton: Edward Elgar.

Javorcik, B. S. - Lo Turco, A. - Maggioni, D. (2018): New and Improved: Does FDI Boost Production Complexity in Host Countries? The Economic Journal, 128(614): 2507-2537.

Krugman, P. (1991): Increasing Returns and Economic Geography. Journal of Political Economy, 99(3): 483-499.

Lengyel, B. - Leydesdorff, L. (2011): Regional Innovation Systems in Hungary: The Failing Synergy at the National Level. Regional Studies, 45(5): 677-693.

Lengyel, B. - Leydesdorff, L. (2015): The Effects of FDI on Innovation Systems in Hungarian Regions: Where is Synergy Generated? Regional Statistics, 5(1): 3-24.

Lengyel, B. - Szakálné Kanó, I. (2013): Related Variety and Regional Growth in Hungary: Towards a Transition Economy Approach. Regional Statistics, 3: 98-116.

Lengyel, B. - Szakálné Kanó, I. (2014): Regional Economic Growth in Hungary 1998-2005: What Does Really Matter in Clusters? Acta Oeconomica, 64(3): 257-285.

Lo Turco, A. - Maggioni, D. (2019): Local Discoveries and Technological Relatedness: The Role of MNEs, Imports and Domestic Capabilities. Journal of Economic Geography, 19(5): 1077-1098.

Marwah, K. - Tavakoli, A. (2004): The Effect of Foreign Capital and Imports on Economic Growth: Further Evidence from Four Asian Countries (1970-1998). Journal of Asian Economics, 15(2): 399-413.

North, D. C. (1955): Location Theory and Regional Economic Growth. Journal of Political Economy, 63(3): 243-258.

Nölke, A. - Vliegenthart, A. (2009): Enlarging the Varieties of Capitalism: The Emergence of Dependent Market Economies in East Central Europe. World Politics, 61(4): 670-702.

Pavlínek, P. - Žížalová, P. (2016): Linkages and Spillovers in Global Production Networks: Firm-Level Analysis of the Czech Automotive Industry. Journal of Economic Geography, 16(2): 331-363.

Phelps, N. A. (2008): Cluster or Capture? Manufacturing Foreign Direct Investment, External Economies and Agglomeration. Regional Studies, 42(4): 457-473. 
Radosevic, S. (2002): Regional Innovation Systems in Central and Eastern Europe: Determinants, Organizers and Alignments. The Journal of Technology Transfer, 27(1): 87-96.

Resmini, L. (2007): Regional Patterns of Industry Location in Transition Countries: Does Economic Integration with the European Union Matter? Regional Studies, 41(6): 747-764.

Rogerson, P. A. (2001): Statistical Methods for Geography. London - Thousand Oaks - New Delhi: SAGE Publications.

Sass, M. (2003): Competitiveness and Economic Policies Related to Foreign Direct Investment. Mimeo, Ministry of Finance of Hungarian Government, Working Paper, No. 3.

Sass, M. - Szalavetz, A. (2014): R\&D-based Integration and Upgrading in Hungary. Acta Oeconomica, 64(Supplement 1): 153-180.

Šipikal, M. - Buček, M. (2013): The Role of FDIs in Regional Innovation: Evidence from the Automotive Industry in Western Slovakia. Regional Science Policy \& Practice, 5(4): 475-490.

Soci, A. (2003): FDI: A Difficult Connection between Theory and Empirics. In: Fingleton, B. (ed.): New Directions in Economic Geography. Cheltenham - Northampton: Edward Elgar, pp. 277-314.

Szakálné Kanó, I. - Lengyel, B. - Elekes, Z. - Lengyel, I. (2019): Agglomeration, Foreign Firms and Firm Exit in Regions Under Transition: The Increasing Importance of Related Variety in Hungary. European Planning Studies, 27(11): 2099-2122.

Young, S. - Hood, N. - Peters, E. (1994): Multinational Enterprises and Regional Economic Development. Regional Studies, 28(7): 657-677.

Open Access. This is an open-access article distributed under the terms of the Creative Commons Attribution 4.0 International License (https://creativecommons.org/licenses/by/4.0/), which permits unrestricted use, distribution, and reproduction in any medium, provided the original author and source are credited, a link to the CC License is provided, and changes - if any - are indicated. (SID_1) 